\title{
The Worth and the Significance of Port in Economic Integration Development Model: A Case Study on Yangtze River Economic Belt China
}

\author{
Liang Wang*, Weiguang Gong*\#, Wei Song, Zhen Xie \\ The School of Public Affairs, University of Science and Technology of China, Hefei, China \\ Email: "gongwg2580@163.com
}

Received 27 October 2015; accepted 5 December 2015; published 10 December 2015

Copyright (C) 2015 by authors and Scientific Research Publishing Inc.

This work is licensed under the Creative Commons Attribution International License (CC BY).

http://creativecommons.org/licenses/by/4.0/

\section{(c) (i) Open Access}

\section{Abstract}

For almost a century, from advancement's perspective of the improvement of port urban communities around the globe, the improvement level of the port has ended up one of the images to quantify monetary improvement level of port city and port neighboring economy has turned into an imperative power to advance financial improvement in port city and district. At present, the hypothetical examination on the advancement of port neighboring economy for the most part pack in the beach front ports, on the other hand, in actuality port neighboring economy in most inland ports likewise grew gradually for a few reasons of geological position, being far from the ocean. With the world's busiest inland water transportation course and its most inland waterway all out payload throughput on the planet in Yangtze River economy belt, port neighboring monetary improvement potential is enormous. This paper will draw motivation by breaking down outside port neighboring economic model, beginning with the advancement status of inland ports in the Yangtze River monetary zone, to give the premise and the proposal for the port neighboring economic joining model of Yangtze River economic belt.

\section{Keywords}

Port Neighboring Economy, Yangtze River Economic Belt, Economic Integration, Development Model

\footnotetext{
*The first two authors contributed equally.

"Corresponding author.
} 


\section{Introduction}

From the perspective of the history of world economic development, the port city has been the most dynamic and vibrant region around the world, with logistics distribution, element agglomeration, industry concentration and economic prosperity. The American city groups such as New York, Los Angeles, Germany Rhine river coast, Japanese industrial zone along with the Pacific as well as Singapore, Hong Kong, etc., are all built in accordance with ports and florieshed., Until today they are still leading the world's economic development trend, it can be said that the port city's economy has become an important part of the world economy [1]-[4]. Hence, to strengthen harbor neighboring economy is no doubt an inevitably choice to develop and revitalize a port city.

Port neighboring economy is a kind of regional economic pattern, through which industry cluster developed relying on the port (including airport, harbor, river port and land port). Mainly with its adjacent area as the center; as the carrier, with comprehensive transportation service system as the artery, with port-related industries as support and it develops characteristic economy, which is closely related to the port, so as to promote regional economic prosperity and development.

This idea has been broadly perceived in the scholarly hover of China [4]-[7]. The current examination about the port neighboring economy mostly move in the harbor monetary zone improvement design, yet the exploration of inland waterway port is generally scarce [8]-[11], just a little measure of the exploration talk about basically about the port economy, port administration, port transportation framework, modern format, and how port and city interact [12]-[18], on the other hand, the investigation and specific examination of port neighboring economy's general advancement design in the inland stream port is clearly deficient.

Relying on the golden waterway, Yangtze River economic belt is a part of China's national regional economic development strategy, traveling the west, the central, and eastern of China, covering 11 provinces, 600 million population, as well as many inland ports, owning more than $40 \%$ of the national population and gross domestic product, it is the biggest economic zone with the biggest density in addition to the developed coastal areas in China. The superior water transport system and broad economic hinterland create conditions for the port neighboring economic development of the Yangtze River economic belt. Developing port neighboring economy is expected to reduce the development gap between east and west of China, and it has practical significance to promote economic development of the Yangtze River economic belt even of the whole country [19] [20]. Therefore, beginning with the present situation and characteristics of the Yangtze River economic belt, this article will summarize port neighboring economic development model of foreign developed post area, then carry on the system analysis to the development environment of port neighboring economy in Yangtze River economic belt, in order to find out the patterns and rules adapted to the port neighboring economic development of the Yangtze River economic belt through drawing lessons from foreign experience of port neighboring economy.

\section{The Status Quo and Characteristics of Ports in Yangtze River Economic Belt}

As per the exploration of United Nations Conference on Trade and Development in 1992 and 1999, the port's advancement can be separated into four stages [21], as in Table 1. As the land and/or water capable transportation hub and center point, Ports assume a critical part in the designation of assets and materials course of a nation or area, and they have dependably been vital connection and transporter of the nations or locales to open to the public [22].

The United Nations conference on trade and development divided each generation of the port according to sequence of time, but from historical background of function change in every generation of port, we can see that this sequence is general trajectory influenced by productivity and economic trade only in the specific historical period. In practice, the function, the location and the conditions of the port will affect the development of the port, the port develop not necessarily from the first generation to the fourth generation, but according to the actual economic needs of the decision. For example, Hong Kong did not experience the second generation of port neighboring industrial stage, but became the fourth generation of international shipping center directly. Thus, the evolution of the port function can be across the stage, rather than step-wise.

Yangtze River economic belt comprises of the inland ports along the Yangtze River and the harbor of Jiangsu, Shanghai and Zhejiang, this paper mainly thinks about the inland ports along the Yangtze River. The aggregate voyage of Yangtze River water transportation is $70,000 \mathrm{~km}$, of which the fundamental safe mileage is $2713 \mathrm{ki}$ lometers, from Yibin of Sichuan area in the west to Yangtze River estuary in the east, with principle ports of Chongqing, Yichang, Chengjiling, Wuhan, Jiujiang, Wuhu, Nanjing, Zhenjiang, Suzhou, Nantong along the Yangtze River as the sponsorship, with enormous, little and medium-sized ports joined, work with the blend of metal water, and public water, stream and ocean. Port conveyance appeared, principle ports appeared in Table 2. 
Table 1. The division and the characteristics of port development stage.

\begin{tabular}{|c|c|c|c|c|}
\hline Stage & First generation & Second generation & Third generation & Fourth generation \\
\hline Years & Before 1950 & $1950-1980$ & $1980-1990$ & After 1990 \\
\hline $\begin{array}{l}\text { Main } \\
\text { cargo }\end{array}$ & General bulk cargo & $\begin{array}{l}\text { General cargo; } \\
\text { Solid bulk; } \\
\text { Liquid bulk; }\end{array}$ & $\begin{array}{l}\text { Solid bulk; } \\
\text { Liquid bulk; } \\
\text { Container bulk }\end{array}$ & Container bulk \\
\hline Service mode & Port to port & $\begin{array}{l}\text { Point to point in part of } \\
\text { connected transportation }\end{array}$ & $\begin{array}{l}\text { Door to door in } \\
\text { multimodal transportation }\end{array}$ & $\begin{array}{l}\text { The whole journey, whole } \\
\text { network, whole process, } \\
\text { multilevel, network to } \\
\text { network in personalized servi }\end{array}$ \\
\hline $\begin{array}{l}\text { Functional } \\
\text { service }\end{array}$ & $\begin{array}{l}\text { Provide the water and } \\
\text { land transportation } \\
\text { services such as ship } \\
\text { dock, passenger } \\
\text { transportation, cargo } \\
\text { loading and } \\
\text { unloading, } \\
\text { transshipment and } \\
\text { storage }\end{array}$ & $\begin{array}{l}\text { Strengthen the function } \\
\text { of industrial and } \\
\text { commercial services } \\
\text { and urban communities, } \\
\text { the port cargo got } \\
\text { appreciation and became } \\
\text { a transportation } \\
\text { center and service center }\end{array}$ & $\begin{array}{l}\text { To strengthen the relationship } \\
\text { with the city and the user, } \\
\text { increase the information } \\
\text { services of transportation and } \\
\text { trade, as well as integrated } \\
\text { services such as the } \\
\text { distribution of goods, to } \\
\text { make port become } \\
\text { international logistics } \\
\text { center and trade logistics base }\end{array}$ & $\begin{array}{l}\text { With the city as the main } \\
\text { body, with free trade as the bas } \\
\text { to provide the integration servi } \\
\text { of production, logistics, } \\
\text { information, trade, finance } \\
\text { and other services about } \\
\text { resources and production facto } \\
\text { to make the port become the } \\
\text { logistics supply chain center }\end{array}$ \\
\hline $\begin{array}{l}\text { The main } \\
\text { features }\end{array}$ & $\begin{array}{l}\text { Single goods flow, } \\
\text { low value-added }\end{array}$ & $\begin{array}{l}\text { Goods flow, combined } \\
\text { services, and increase } \\
\text { the value added }\end{array}$ & $\begin{array}{l}\text { Goods information flow, } \\
\text { integrated logistics services } \\
\text { such as sub transportation, } \\
\text { distribution and distribution, } \\
\text { as well we entire } \\
\text { transport, high value-added }\end{array}$ & Integrated logistics services \\
\hline $\begin{array}{l}\text { Strategy } \\
\& \\
\text { status }\end{array}$ & $\begin{array}{l}\text { For the post-war } \\
\text { economy } \\
\text { water and land } \\
\text { transportation hub; } \\
\text { depending port of } \\
\text { center city }\end{array}$ & $\begin{array}{l}\text { Industry oriented } \\
\text { water and land } \\
\text { transportation hub; } \\
\text { traditional logistics } \\
\text { shipment center; } \\
\text { important central } \\
\text { depending port }\end{array}$ & $\begin{array}{l}\text { Business oriented; } \\
\text { integrated logistics service } \\
\text { center; Regional energy } \\
\text { security transshipment hub port; } \\
\text { the modern comprehensive } \\
\text { transportation hub; container } \\
\text { transport trunk base port; the } \\
\text { international deep-water } \\
\text { port of transshipment }\end{array}$ & $\begin{array}{l}\text { Ocean oriented; } \\
\text { international port and } \\
\text { waterway alliance; the } \\
\text { international center for } \\
\text { marine economic } \\
\text { development; marine } \\
\text { industry comprehensive } \\
\text { distribution hub }\end{array}$ \\
\hline
\end{tabular}

The

Talent and environment

(Data sources: The United Nations conference on trade and development Port service sales and the challenges of the third generation port- - The secretariat report of The United Nations conference on trade and development (January 1992)).

Before the end of 2014, there are 4079 generation billets alone the storage compartment line of Yangtze River, 477 billets which more than 10,000 tons , the principle ports have the accompanying qualities.

\subsection{Cargo Throughput Volume Is Huge; The Downstream Port Is the Development Core}

According to the statistics of ministry of transport in 2014, in addition to Shanghai port, cargo throughput in the other ports (10,000,000 T above) of Yangtze River trunk was 19.9 tons, stood at the first place in the total amount of the world's inland river shipping. Among them, the foreign trade cargo throughput reached 2.63 tons, container throughput reached 12,955,000 TEU. From the partition of situation, throughput in middle reaches increased at the fastest rate, throughput in downstream increased at the lowest rate, the port cargo throughput of the upper middle and lower reaches completed 178 million tons, 209 million tons, 209 million tons, year-on-year growth of $8.7 \%, 17.0 \%$ and $5.9 \%$, respectively, among them, port cargo throughput downstream occupied the largest proportion, at $80.5 \%$. As shown in Table 2, Nanjing port and Nantong port downstream exceeded 200 million tons, cargo throughput of Suzhou port was nearly 480 million tons, ranked seventh in the top 10 at the global port cargo throughput in 2014, and Suzhou port was the only inland port. (Statistics on the transport department and the China port network). 
Table 2. The main inland port neighboring economic conditions alone Yangtze River economic belt.

\begin{tabular}{|c|c|c|c|c|c|c|c|}
\hline \multirow[b]{2}{*}{ Port } & \multicolumn{2}{|c|}{ Throughput in 2014} & \multirow[b]{2}{*}{$\begin{array}{l}\text { Main port neighboring } \\
\text { industry }\end{array}$} & \multirow[b]{2}{*}{ Main function } & \multirow[b]{2}{*}{ Development goals } & \multirow[b]{2}{*}{ Type of port } & \multirow[b]{2}{*}{$\begin{array}{l}\text { Development } \\
\text { stage }\end{array}$} \\
\hline & $\begin{array}{l}\text { The } \\
\text { goods } \\
\text { (ten } \\
\text { thousand } \\
\text { tons) }\end{array}$ & $\begin{array}{l}\text { Container } \\
\text { (ten } \\
\text { thousand } \\
\text { TEU) }\end{array}$ & & & & & \\
\hline $\begin{array}{l}\text { Shanghai } \\
\text { port }\end{array}$ & 75,529 & 3520 & $\begin{array}{l}\text { Automobile and } \\
\text { parts, Ocean } \\
\text { engineering, } \\
\text { The airline industry, } \\
\text { Modern } \\
\text { logistics industry }\end{array}$ & $\begin{array}{l}\text { The center of service } \\
\text { supply chain }\end{array}$ & $\begin{array}{l}\text { Logistics supply chain } \\
\text { center; } \\
\text { International shipping } \\
\text { center }\end{array}$ & $\begin{array}{c}\text { International } \\
\text { service port }\end{array}$ & $\begin{array}{l}\text { The fourth } \\
\text { generation }\end{array}$ \\
\hline $\begin{array}{l}\text { Suzhou } \\
\text { port }\end{array}$ & 47,900 & 445 & $\begin{array}{l}\text { Petrochemical, } \\
\text { chemical, modern } \\
\text { logistics industry }\end{array}$ & $\begin{array}{l}\text { International } \\
\text { logistics center }\end{array}$ & $\begin{array}{c}\text { Port }+ \text { industry + } \\
\text { logistics }+ \text { new } \\
\text { port city; } \\
\text { International shipping } \\
\text { center }\end{array}$ & $\begin{array}{c}\text { International } \\
\text { service port }\end{array}$ & $\begin{array}{l}\text { The third } \\
\text { generation }\end{array}$ \\
\hline $\begin{array}{l}\text { Nanjing } \\
\text { port }\end{array}$ & 22,351 & 276 & $\begin{array}{l}\text { Electronics, medicine, } \\
\text { modern logistics } \\
\text { industry }\end{array}$ & $\begin{array}{l}\text { International } \\
\text { logistics center }\end{array}$ & $\begin{array}{l}\text { The Yangtze River } \\
\text { shipping center }\end{array}$ & $\begin{array}{l}\text { International } \\
\text { service port }\end{array}$ & $\begin{array}{l}\text { The third } \\
\text { generation }\end{array}$ \\
\hline $\begin{array}{l}\text { Nantong } \\
\text { port }\end{array}$ & 22,806 & 71 & $\begin{array}{l}\text { Ship building, } \\
\text { petrochemical, } \\
\text { modern } \\
\text { logistics industry }\end{array}$ & $\begin{array}{l}\text { International } \\
\text { logistics center }\end{array}$ & $\begin{array}{l}\text { Shanghai international } \\
\text { shipping center }\end{array}$ & $\begin{array}{l}\text { International } \\
\text { service port }\end{array}$ & $\begin{array}{l}\text { The third } \\
\text { generation }\end{array}$ \\
\hline $\begin{array}{l}\text { Huzhou } \\
\text { port }\end{array}$ & 8483 & 12 & $\begin{array}{l}\text { Nc machine tools, } \\
\text { equipment } \\
\text { manufacturing, and } \\
\text { logistics industry }\end{array}$ & $\begin{array}{l}\text { Transportation center, } \\
\text { service center of } \\
\text { industry and } \\
\text { commerce }\end{array}$ & $\begin{array}{l}\text { Yangtze River delta } \\
\text { region transportation hub }\end{array}$ & $\begin{array}{c}\text { Large } \\
\text { professional } \\
\text { logistics port }\end{array}$ & $\begin{array}{l}\text { The second } \\
\text { generation }\end{array}$ \\
\hline $\begin{array}{l}\text { Zhenjing } \\
\text { port }\end{array}$ & 14,029 & 37 & $\begin{array}{l}\text { Chemical industry, } \\
\text { paper making, } \\
\text { building materials, } \\
\text { the logistics industry }\end{array}$ & $\begin{array}{l}\text { Transportation center, } \\
\text { service center of } \\
\text { industry and } \\
\text { commerce }\end{array}$ & Transit service center & $\begin{array}{c}\text { Large } \\
\text { professional } \\
\text { logistics port }\end{array}$ & $\begin{array}{l}\text { The second } \\
\text { generation }\end{array}$ \\
\hline $\begin{array}{l}\text { Taizhou } \\
\text { port }\end{array}$ & 15,621 & 19 & $\begin{array}{l}\text { Food processing, } \\
\text { marine medicine } \\
\text { materials, modern } \\
\text { logistics }\end{array}$ & $\begin{array}{l}\text { Transportation center, } \\
\text { service center of } \\
\text { industry and } \\
\text { commerce }\end{array}$ & $\begin{array}{l}\text { The Yangtze River } \\
\text { downstream integrated } \\
\text { transport hub }\end{array}$ & $\begin{array}{c}\text { Large } \\
\text { professional } \\
\text { logistics port }\end{array}$ & $\begin{array}{l}\text { The second } \\
\text { generation }\end{array}$ \\
\hline $\begin{array}{l}\text { Chongqing } \\
\text { port }\end{array}$ & 14,538 & 102 & $\begin{array}{l}\text { Biological medicine, } \\
\text { precision instruments, } \\
\text { bonded logistics }\end{array}$ & Modern logistics & $\begin{array}{l}\text { Import and export trade } \\
\text { center; The Yangtze } \\
\text { River shipping center }\end{array}$ & $\begin{array}{l}\text { Regional } \\
\text { service port }\end{array}$ & $\begin{array}{l}\text { The second } \\
\text { generation }\end{array}$ \\
\hline $\begin{array}{l}\text { Yueyang } \\
\text { port }\end{array}$ & 11,270 & 22 & $\begin{array}{l}\text { Equipment } \\
\text { manufacturing, } \\
\text { new materials, } \\
\text { modern logistics }\end{array}$ & $\begin{array}{l}\text { Transportation center, } \\
\text { service center of } \\
\text { industry and commerce }\end{array}$ & $\begin{array}{l}\text { Shipping center in the } \\
\text { middle reach of } \\
\text { Yangtze River }\end{array}$ & $\begin{array}{c}\text { Large } \\
\text { professional } \\
\text { logistics port }\end{array}$ & $\begin{array}{l}\text { The second } \\
\text { generation }\end{array}$ \\
\hline Wuhu port & 10,837 & 40 & $\begin{array}{l}\text { Automobile and parts, } \\
\text { building materials, } \\
\text { electronic appliances, } \\
\text { modern logistics }\end{array}$ & $\begin{array}{l}\text { Transportation center, } \\
\text { service center of } \\
\text { industry and } \\
\text { commerce }\end{array}$ & $\begin{array}{l}\text { Anhui international } \\
\text { container hub port }\end{array}$ & $\begin{array}{c}\text { Large } \\
\text { professional } \\
\text { logistics port }\end{array}$ & $\begin{array}{l}\text { The second } \\
\text { generation }\end{array}$ \\
\hline $\begin{array}{l}\text { Wuhan } \\
\text { Xingang }\end{array}$ & 15,000 & 100 & $\begin{array}{l}\text { Heavy equipment, } \\
\text { petrochemical } \\
\text { industry, modern } \\
\text { logistics }\end{array}$ & $\begin{array}{l}\text { Transportation center, } \\
\text { service center of } \\
\text { industry and } \\
\text { commerce }\end{array}$ & $\begin{array}{l}\text { Shipping center in the } \\
\text { middle reach of } \\
\text { Yangtze River }\end{array}$ & $\begin{array}{c}\text { Large } \\
\text { professional } \\
\text { logistics port }\end{array}$ & $\begin{array}{l}\text { The second } \\
\text { generation }\end{array}$ \\
\hline $\begin{array}{l}\text { Tongling } \\
\text { port }\end{array}$ & 7045 & 2.68 & $\begin{array}{l}\text { The sources of energy, } \\
\text { raw materials, logistics }\end{array}$ & $\begin{array}{l}\text { Transportation center, } \\
\text { service center of } \\
\text { industry and } \\
\text { commerce }\end{array}$ & Regional logistics hub & $\begin{array}{c}\text { Large } \\
\text { professional } \\
\text { logistics port }\end{array}$ & $\begin{array}{l}\text { The second } \\
\text { generation }\end{array}$ \\
\hline
\end{tabular}

Data source: 1) China shipping database network http://www.shippingdata.cn/index.html; 2) China port network http://www.chinaports.com/thruput. 


\subsection{Port Capacity in the Center and Upper Ranges Is Single; Port Neighboring Economy Advancement Lingers Behind}

In spite of the fact that the port payload throughput in center and upper compasses of Yangtze River developed quick, and port freight throughput in ports of Zhenjiang, Yangzhou, Taizhou, Jiangyin, Chongqing, Yueyang, Wuhu, Wuhan Newport surpassed billions of dollars, in any case, the port development grew moderate, and the capacity was single, with load taking care of, warehousing and logistics as its principle capacities, likewise the port neighboring industry was commanded by the logistics business and in addition port neighboring industry and trade.

\subsection{Give Priority to with Bulk Transportation, and the Specialization Degree on Container Is Low}

Coal and metal products, metal mineral, mineral building materials and other bulk commodities were major commodities of the Yangtze River shipping. In 2014, throughput of coal and metal products, metal ore, ore material in the Yangtze River trunk accounted for 23.3\%, 20.7\% and 17.0\% of total throughput respectively, and the total accounted for $61 \%$ of the Yangtze River shipping amount. Although specialized transport growth accelerated in recent years, such as container, but the total amount was still very few. For example, cargo throughput of Taizhou port was 156.21 million T, by comparison of that container throughput was only less than 200,000 TEU, also container throughput of Tongling port was less than 30,000 TEU.

\section{Analysis of Port Neighboring Economy Development Mode in Foreign Countries}

Port neighboring economy was a kind of economic form which mainly rely on the port and port neighboring region to carry out industry layout [23], the choice of its development mode and port development were closely linked. Through analyzing port neighboring economic development model from all over the world, we think that basically has the following three modes.

\section{1. "Port + Logistics" Model}

In the beginning of port neighboring economic development, most of the ports in the world choose port neighboring economic development pattern from the aspect of logistics based on the function of cargo loading and unloading as well as transportation. According to the development process of the port, multimodal transportation is the foundation of port neighboring economic development. In the process of developing port neighboring economy, Germany combined the location and transportation advantages of ports, and established multimodal transport system with full convergence and efficient organization, including river and see, water rail as well as water highway, made ports become important hub ports in the comprehensive transportation system, improved the logistics efficiency and reduced logistics cost effectively, so as to promote regional economic development [24]. For example, as Germany's biggest inland river port, Duisburg port began to appear as goods distribution center which is given priority to with water transportation in the 12th century. At the beginning of the 20th century, Duisburg began to construct railway station, and built the canal connecting the ports at the same time, made it possible to combine railway and water transportation. In the 1980s, Duisburg port began to link the inland shipping and coastal transportation through the railway and inland river shipping. In the 1990s, with the adjustment of the economic structure of Duisburg, the government has strengthened the construction and transformation of the port infrastructure, so that the water, railway and highway transportation modes link effectively. Since the 21st century, Duisburg port carry out close cooperation with foreign ports through the multimodal system, and participate in the modern logistics and international supply chain actively, has already become the largest inland port in the world [25].

\section{2. "Port + Logistics + Port Neighboring Industry" Mode}

The advancement of port neighboring economic improvement can't manage without its own port advancement, port improvement likewise can't manage without the social monetary advancement. After World War II, the recuperation and thriving of the worldwide economy advanced the fast advancement of the port, and the development of the essential railroad, interstate, which are associated with the port, has been enhanced [26], helpful 
movement shape a group impact to the business [27], industry, business and transportation administration started to assemble at the port [28], the industrialization of port zone has turned into the center of port neighboring territorial monetary improvement [8] [20] [29], numerous created nations expand efficiency adequately depending on harbor industry and has accomplished wonderful financial advantages [30].

For example, with a name of "gateway for Germany to move toward the world”, the port of Hamburg is currently the quasi third generation port, which is the first in German and the second in European, its port economic development model is worthy of study. The port of Hamburg locates in Central Europe, in the right side of Elbe River downstream in northern Germany, on the verge of Heligoland bight, 120km away from estuary of the North Sea, with depth of 16 meters in channel water, and with 10 million T navigable for tanker; meanwhile, Hamburg is a important railroad and aviation hub in Germany, rivers arrange in a crisscross pattern and there are many bridges inside the city, crossing tunnels interlink at the bottom of North River, Hamburg provides a very mature transport service for the port from many aspects. Under the conditions of superior ports and the convenient integrated transport network environment, on the one hand, Hamburg Port kept on improving the port facilities.

Since 1960, an expansive number of cutting edge compartment terminals, substantial capacity yards, oil warehouses have been developed, and then again, Hamburg expanded the logistics' development channels. At present, almost 300 courses of Hamburg Port stay in touch with more than 1100 ports on five landmasses on the planet. In 2001, another compartment railroad was inherent Hamburg, the railroad lines stretch out all through all ports, and products can be straightforwardly stacked and emptied between rail line carriage and boat, which can achieve the Eastern European nations specifically. Also, the multimodal transport administration system can extend its inventory network to ports in the far east along the Eurasian mainland bridge, such as Lianyungang port and Shenzhen port in China.

It is more worth mentioning that Hamburg port kept on developing port neighboring industry since the 1960s. At present Hamburg port has a land area of nearly 60 square kilometers, 20 square kilometers of industrial and commercial land, the industry development planning is mainly from east to west along the Elbe, except the shipbuilding industry, refining industry and industry which finish foreign raw material, there are main service industry such as commercial and logistics.

Predominant port assets and helpful incorporated activity system of Hamburg port draw in about 2 million seagoing vessels to go all through the port each year, which lay the Hamburger harbor's logistics status, make it turn into an essential conveyance focus in eastern Europe and the logistics center which dives deep into eastern locale of Europe; additionally they advance the port neighboring industry to assemble in the ports, make Hamburg Port turn into the focal point of the shipbuilding business and the second biggest modern base in Germany.

\section{3. "Port + City" Model}

Ports and cities always have close contact in economy, port is the foundation and driving force to develop economy for the port neighboring city, and in turn, urban economy is the carrier and support for the development of port. With the continuous development of social economy and under the mechanism of mutual promotion and mutual dependence, the new port neighboring economic model of integration development of port and city began to appear in some port neighboring cities, Rotterdam is a typical example. Located in the estuary of Rhine and Meuse in Europe, Rotterdam port is the biggest port in Europe, it was built entirely relying on the city of Rotterdam in the Netherlands, and it is one of the port cities which develop integration of port and city successfully in the world [31]. Its characteristics are: on the one hand, the development of Rotterdam City made full use of the advantages of neighboring port. Port Authority, distribution center and port industrial sector, which service for ports, locate within the city, also in the port. Meanwhile, different types of port neighboring industry and logistics parks distribute in the narrow strip near the port. Therefore, there are about 700,000 direct and indirect employees in Rotterdam port, total output value of ports and related auxiliary industry accounted for $12 \%$ of the country's GDP, for 40\% of in Rotterdam City's GDP. On the other hand, since it located in Rotterdam City, which is goods distribution center in Holland and the EU, with convenient port transport conditions, well-developed integrated transportation linking to all continents, and the 500 square kilometers hinterland around the port, which are the most developed regions in Europe, benefit from these factors, Rotterdam port has been one of the world's ten largest ports. It can be seen that Rotterdam was dominated by the developed port economy and Rotterdam port dependent on Rotterdam City and the vast hinterland economy in Europe, which 
manifested the combination of port and city.

\section{Integration Development Model of Port Neighboring Economy in the Yangtze River Economic Belt}

\subsection{Analysis of Port Neighboring Economic Development Environment in Yangtze River Economic Belt}

\subsubsection{Development Promotion of External Environment}

From the aspect of economic globalization, international division and cooperation has become the inevitable trend of the social development, especially with the increasing degree of Chinese economic opening to the outside world, China has become the important part of the global economy, and its frequent foreign trade promotes the port neighboring economic development and rise. From the domestic macroeconomic environment, the Chinese economy has entered a new normal, from the high speed growth to middle and high speed growth, from the extensive growth to intensive growth, from the traditional point of growth to a new point of growth. The current traditional economic development model has been unable to meet the needs of social development, thus looking for new economic growth pole has become the inevitable trend of regional economic development. Effect of port neighboring economy in Shanghai, Tianjin and other cities attain more and more attention, its development model was copied and transplanted repeatedly, and provide a reference for the Yangtze River economic belt to participate in international cooperation and seek new economic model. As a golden waterway, whose freight volume ranks the first in inland rivers all around the world, Yangtze River economic belt has unique advantages and should join the field of commodity circulation actively, share the benefit of industry development, with developing port neighboring economy as the driving force, boost port city economic development along the Yangtze River and promote overall economic growth of China.

\subsubsection{Development Needs of Internal Economy}

Nowadays, provinces and cities in the Yangtze River economic belt are in a critical period of transforming development mode and adjusting the industrial structure, economic development situation is not optimistic. As shown in Table 3, statistics from 2012 years to 2014 show that economic growth in 9 provinces and 2 cities, which belong to Yangtze River economic belt, continued to decline, seeing on the data of the first quarter in 2015, in addition to the economic growth in Zhejiang Province over the same period last year, the economy continued to decline in other provinces, the pressure of future economic downturn is still relatively large. To find a new development model has become the central task of the Yangtze River economic belt to promote the

Table 3. The economic situation of provinces in Yangtze River economic belt.

\begin{tabular}{|c|c|c|c|c|c|c|c|c|}
\hline & \multicolumn{4}{|c|}{ GDP } & \multicolumn{4}{|c|}{ Growth speed of GDP } \\
\hline & In 2012 & In 2013 & In 2014 & $\begin{array}{c}\text { First } \\
\text { quarter in } 2015\end{array}$ & In 2012 & In 2013 & In 2014 & In 2015 \\
\hline Shanghai & 20,101 & 21,602 & 23,561 & 5815.8 & 7.5 & 7.7 & 7 & 6.6 \\
\hline Jiangsu & 54,058 & 59,162 & 65,088 & $14,620.7$ & 10.1 & 9.6 & 8.7 & 8.4 \\
\hline Zhejiang & 34,606 & 37,569 & 40,154 & 8342.4 & 8 & 8.2 & 7.6 & 8.2 \\
\hline Anhui & 17,212 & 19,039 & 20,849 & 4238.3 & 12.1 & 10.4 & 9.2 & 8.6 \\
\hline Jiangxi & 12,949 & 14,339 & 15,709 & 3406.2 & 11 & 10.1 & 9.7 & 9.3 \\
\hline Hubei & 22,250 & 24,669 & 27,367 & 5487.9 & 11.3 & 10.1 & 9.7 & 8.5 \\
\hline Hunan & 22,154 & 24,502 & 27,049 & 5392.3 & 11.3 & 10.1 & 9.5 & 8.4 \\
\hline Chongqing & 11,459 & 12,657 & 14,265 & 3306.7 & 13.6 & 12.3 & 10.9 & 10.7 \\
\hline Guizhou & 6802.2 & 8006.8 & 9251 & 1659.4 & 13.6 & 12.5 & 10.8 & 10.4 \\
\hline Sichuan & 23,850 & 26,261 & 28,537 & 6234.5 & 12.6 & 10 & 8.5 & 7.4 \\
\hline Yunnan & 10,310 & 11,721 & 12,815 & 2613.7 & 13 & 12.1 & 8.1 & 7.2 \\
\hline
\end{tabular}

Remarks: data come from national bureau of statistics website and provincial bureau of statistics website. 
coordinated development of the region. Developing port neighboring economy vigorously and making it become the powerful engine of Yangtze River economic belt is an important measure to conform to the development of the situation, promote regional economic transformation and upgrading, optimize the allocation of resources as well as achieve innovation and development.

\subsubsection{Strategic Positioning of Macro Policy}

Since carrying out the strategies of Western Development and Central Rising, several key economic zones planned later brought an unprecedented policy dividend to Yangtze River economic belt. Since June 2005, the State Council approved the Pudong New Area for the comprehensive reform pilot, the state distributed four comprehensive reform pilot areas in the Yangtze River Basin, Chengdu, Chongqing, Wuhan city circle as well as Changsha, Zhuzhou and Xiangtan city group, and another four state-level development zone planning, coastal area of Jiangsu Province, Wanjiang City zone, Poyang Lake Ecological Economic Zone and Zhoushan new district. In September 2014, the State Council promulgated Guidance of the State Council on promoting the development of the Yangtze River economic belt on the golden waterway and the integrated three-dimensional transport corridor planning in Yangtze River economic belt. Under the superposition of a variety of national macroeconomic policies, the Yangtze River economic belt will be able to enjoy the support of state from many aspects. Therefore, to strengthen the positioning and planning of port neighboring economy alone Yangtze River using the advantage of the policy, integrate various elements, and make port neighboring economy play an effective role, then the regional competitiveness of Yangtze River economic belt will be increasingly prominent.

\subsubsection{Intrinsic Drive of Resource Endowment}

The Yangtze River economic belt has a unique advantage in resources. In terms of natural resources, at first the Yangtze River has shipping lines with long distance and ow cost as well as abundant water resources, secondly the Yangtze River also has many kinds of mineral resources with large reserves, in addition, it has a number of famous tourism resources and rich agricultural biological resources, its development potential is huge. In terms of traffic location, Yangtze River economic belt of trans across the hinterland of China , and has the vast economic hinterland, not only connect the east, middle and west areas, but also intersect with the north-south railway lines of Beijing-Shanghai, Beijing-Jiulong, Beijing-Guangzhou, Anhui-Jiangxi, Jiaozuo-Liuzhou etc., connect East and West, South and north, rivers and seas. In the industry of hinterland, the Yangtze River has always been one of the most important industrial corridors, most essence of Chinese modern industrial gather here, such as iron and steel, automotive, electronics, petrochemical etc., attract a large number of industries with high energy consumption, large volume, high-technology and large enterprises. In addition, the proportion of agriculture also ranks first in the country, grain, cotton, and oil production of nine provinces and cities along the River accounted for more than $40 \%$ of the country. It can be seen that, compared with the coastal and other economic zone, the Yangtze River economic belt has the most extensive hinterland and development space in China, is China's region with largest economic growth potential in the next decade, and should become the River Economic zone with the world's largest development scale and most widely affected area.

\subsection{Relevant Enlightenment of Foreign Port Neighboring Economy Development Mode}

\subsubsection{Port Neighboring Economic Development Mode Is Closely Related to Port Development Stage} According to the division on port development stage of the United Nations Conference on Trade and Development, we found that the development model and the port stage has certain relation in the process of developing port economy relying on the port in some developed countries.

Transfer function is the main and the most basic function in the first generation port, the port neighboring economic development mode is mainly based on logistics and transport industry [32], such as Duisburg port before 1960s. When port turned to the second stage further, attracted and gathered a lot of production factors, the port neighboring economic development model began to turn to port neighboring industrial zone, port industry chain continued to extend in this process and also attracted related industries to gather in the vicinity of the port, kinds of port neighboring industries continued to enter and develop [33], such as Hamburg port after 1960. When port developed from the loading and unloading to integration of loading and unloading, transportation, tourism, industry and logistics, in the leading role of the port industry, a large number of people, logistics and information flow were attracted to gather in port city and drive the agglomeration and development of other in- 
dustries in the continuous accumulation effect, such as the current Hamburg port and Rotterdam port.

\subsubsection{Port Logistics System Is the Basis for the Development of Port Economy}

From the port improvement stage and examination of remote port neighboring economic advancement mode, port logistics exist in all aspects of the port and port monetary improvement, is the premise of port neighboring economic advancement. So as to take care of the demand of endeavors to set up stockroom and conveyance focus in port, world's real ports opened particular zones and outfitted with the important offices to give full administration to undertakings required by warehousing and logistics appropriation [21], it was port logistics advancement that advanced the port's development, and the further fortifying of port advanced the port logistics industry, favorable dissemination framed in the middle of port and logistics and advanced the port neighboring economic improvement viably [23]. Along these lines, in the process to pick port neighboring economic advancement mode, Yangtze River economic belt ought to establish a decent framework for the improvement's design of port neighboring economy from parts of port base, multimodal transportation system and transportation framework development.

\subsubsection{Port Neighboring Industry Is the Core of Port Neighboring Economic Development}

Industry is the backbone of economic development. Certainly port neighboring industry is the key to developing port neighboring economy [34]. Developing port neighboring industry has effects of accumulation of production factors and industrial radiation, can not only provide the required industrial resources for the sustainable development of urban economy, but also make full use of international market to develop regional economy, which is beneficial to expand living space of the enterprise in city. What's more important is that, with exact location, port neighboring industry will induce more related industries to gather and grow in local area, continue to improve the capacity of the regional economy, and increase a substantial employment opportunities [19] [20]. Meanwhile, the aggregation of logistics, information, capital and talent will also be conducive to improve the comprehensive competitiveness of port cities further [35]. The development history of the world famous port economic zones in Japan and Europe shows that, developing related port neighboring industrial, trade and transportation is very effective to stimulate regional economic development, increase employment and tap new economic growth point.

\subsubsection{The Integration of Port and City Is the Trend of Port Neighboring Economic Development}

From the development history of world ports, integration and coordination of port and industry appeared in the second generation, the third generation, emphasize integrated and coordinated development of port, the adjacent area and city; the fourth generation means the port group cooperation as well as port and shipping enterprise integration. At present, the second generation port is still the mainstream of development, but with the economic globalization, the internationalization of the market and information networking, some large ports have begun to transform to the third even fourth generation port. And generally speaking, the fourth generation of the port has vast and convenient traffic and economic hinterland, integrate with the host city, as well as plan and develop the entire city's industrial layout and functional positioning with port as the core. According to the principle of adaption between port neighboring economic development mode and port development stage, integration mode of port, production and city will be common model to develop port neighboring economy in the future.

\subsection{Integration Mode of "Port + Logistics + Industry + City" in the Yangtze River Economic Belt}

In the wake of investigating momentum circumstance of the Yangtze River economic belt, we found that in spite of the fact that the ports of the Yangtze River economic belt are close to the city, with huge amount and high throughput, the second era of port is still the principle mode, and there are numerous issues, for example, that port capacity is single, port neighboring industry improvement lingers behind, offices are deficient, extensive transportation framework is not immaculate and connection in the middle of port and city is insufficient. Contrasted and outside experience on port neighboring monetary improvement said above, we trust that the port neighboring economy of the Yangtze River economic belt ought to pick the coordination advancement method of "port + logistics + industry + city" on the premise of existing port assets and urban economy. Particular prerequisites are as per the following: 


\subsubsection{Make Full Utilization of Port Assets and Quality Port Development}

The Yangtze River economic belt has copious shoreline assets, particularly in the downstream of the Yangtze River after Wuhu port, with wide water surface of the channel, more than 12 meters water profundity and all around created economy of port city, The Yangtze River economic belt ought to make utilization of the superb assets adequately, particularly top notch shoreline assets to extend port development. On the other hand, the vast majority of the port development in the Yangtze River, particularly those in the center and upper compasses, is still moderately in reverse, the foundation offices can not address the issues of port advancement. Along these lines, present day investigative and innovative means should be utilized to modify port framework, stacking and emptying hardware, in order to enhance the productivity and nature of operation.

\subsubsection{Accelerate the Improvement of Logistics System}

At present, service provided by the ports along the Yangtze River is mainly oriented to waterway cargo handling, storage and highway-waterway logistics, which is relatively simple. Therefore, on the one hand, the ports need to speed up the comprehensive transportation network construction of railway, highway, waterway and airline to promote the integration of multi-transport. On the other hand, to develop modern logistics, transport services, information services, financial services and warehousing services through the port neighboring city, give full play to the integrated services functions of the port city, form various services around trade demand, and provide function-complete logistics platform, so as to build the logistics center of port city, as well as regional distribution center of people, logistics, capital and information.

\subsubsection{Develop Unrivaled Industry of Neighboring Port}

Port neighboring industry is entitative backing of port neighboring local economy, and is exceptionally shut to port improvement, framing mechanical groups with column commercial enterprises as the center is a conspicuous component of the port neighboring monetary advancement. Along these lines, the Yangtze River economic belt ought to pick the better business which is extremely shut than port asset on the base of the diverse urban communities and locales where every port finds and consider the port area, capacity and incorporated transport conditions, advancement qualities of monetary hinterland and also asset conditions thoroughly. In the interim, to accelerate the development of the port neighboring modern park, coordinate assets further, elevate the recreation center to create with scale and qualities, in order to frame another development shaft to advance territorial financial improvement.

\subsubsection{Advance Positive Connection in the Middle of Port and City}

Partnership of port and city is the all inclusive model of worldwide organized commerce zone. The Yangtze River economic belt ought to set up port neighboring modern park in the middle of port and city, quality the relationship in the middle of port and city, coordinate urban creation elements utilizing the benefits of port as a part of the port neighboring mechanical stop, and investigate new financial development point, in order to advance the regular improvement of port and city. In the meantime, set up unhindered commerce zone in the port, advance the development of free port with the impact of the port neighboring logistics park, to understand the collaboration of capacity and correlative points of interest between fortified zone and port locale.

\section{Conclusion}

Obviously, creating port neighboring economy cannot turn into a reason for port extension, regardless of what sort of mode is completed to create port neighboring economy, things should be considered, such as how to utilize serious assets, to improve the level and productivity of port advancement, to advance operation proficiency of industry which is port connected with port, and to frame the modern chain and industry bunches. Furthermore, port neighboring economy advancement in Yangtze River economic belt is in the beginning stage, in this way the port neighboring economy improvement ought to be arranged, additionally the business choice and format, port development, and also natural assurance ought to be completed under the arranging's direction and take after the laws of port neighboring monetary improvement.

\section{Acknowledgements}

This research was supported by the Research Grants Projects of the Anhui Province Economic and Social De- 
velopment, China.

\section{References}

[1] Takeuchi, Y. (1989) Development and Evaluation Methods of Ports. China Communication Press, Beijing.

[2] Porter, M.E. (2000) Competition, and Economic Development: Local Clusters in the Global Economy. Economic Development Quarterly, 14, 15-34. http://dx.doi.org/10.1177/089124240001400105

[3] An, X.G. and Wei, L.H. (2008) International Experiences and Inspiration for the Development of Port Neighboring Economy. Journal of Guangzhou City Polytechnic, 8, 67-72.

[4] Ye, J.H. (2008) International Experience and Inspiration of Development of Port Neighboring Economy. China Water Transport, 4, 4-6.

[5] Chen, J.S. (2008) The Internal Relationship between Harbors and the Economic Growth Pole of the Seaports. Shanghai Jiao Tong University, 1, 18-19.

[6] Wang, J.H. (2007) The Compare of Caofeidian Port and Chiba Port and Its Significance. Port Economy, 10, 32-34.

[7] Zhu, L.Y. (2011) Research City and Hinterland Dual-drive Push Model on Inland Port-Neighboring Economy. Southwest Jiaotong University, Chengdu.

[8] Pinder, D. (1988) Seaport and European Energy System. Revitalizing. Belhaven Press, London, 20-39.

[9] Wu, C.G. and Gao, X.Z. (1989) Seaport City Growth Patterns. Geographical Research, 4, 9-15.

[10] Tian, R.G. (1996) Production Mode of the World's Large-Scale Production Formed by Largest Industrial Port-Neighboring. China Ports, 5, 23-26.

[11] Zhang, J.Q. (1998) The Establishment and Evolution of Port-Neighboring Industrial Development Zone. Economic Geography, 8, 36-42.

[12] Hoyle, B.S. (1989) The Port-City Interface: Trends, Problems and Examples. Geoforum, 20, 429-435. http://dx.doi.org/10.1016/0016-7185(89)90026-2

[13] Ducruet, C. (2005) Comparing European and East Asian Port Cities: Are Global Databases Relevant Sources for Research? Geography, 17,139-159.

[14] Domenici, A. (1999) The Connection of Port and City. The Dock \& Handbook Authority, 5, 43-64.

[15] Li, N. (2007) The Study of the Connotation and Border of the Port-Neighboring Industrial Clusters. Port Economy, 11, 40-42.

[16] Luo, Z.Q. (1991) Port Economics. Academy Press, Beijing.

[17] Yu, L.Q. (2009) Review of Port and City Relations Theory. Liaoning Economy, 4, 42-43.

[18] Yang, W. and Yue, G. (2008) Constructing the Relationship of Port and City for Modern Port City. Economic Geography, 2, 209-213.

[19] Pollock, E.E. (1973) Ports, Port Hinterland and Regional Development. The Bulletin, Japan Maritime Research Institute, Tokyo, 132-143.

[20] Pollock, E.E. (1981) Free Ports, Free Trade Zones, Export Processing Zones and Economic Development. In: Hoyle, B.S. and Pinder, D.A., Eds., Cityport Industrialization and Regional Development, Belhaven Press, London, 37-45.

[21] Yang, Q. (2013) A Study on the Integration of Inland Port Industrial Space and Urban Space. Shanghai Jiao Tong University, Shanghai.

[22] Xie, W.N. and Zheng, J.C. (2011) Modification on the Port Development Mode and Promote Related Comprehensive Logistics Systems. Research on Waterboren Transportation, 2, 34-38.

[23] Li, Y. (2007) Development Mode of Port Neighboring Economy in Developed Countries and Inspiration to Dalian. Port Economy, 7, 48-50.

[24] Yang, M.X. (2008) Experience and Inspiration of Port Construction and Development of Port Industry. Policy Outlook, 3, 24-24.

[25] Escher, G. (1999) Ausbau des Duisburger Innenhafens. http://www.innenhafen-portal.de/standort/html/rundgang.html

[26] Hayuth, Y. (1987) Intermodality: Concept and Practice. Lloyd's of London Press, London.

[27] Mori, T. and Nishikimi, K. (2002) Economies of Transport Density and Industrial Agglomeration. Regional Science and Urban Economic, 32, 167-200. http://dx.doi.org/10.1016/S0166-0462(01)00078-3

[28] Slack, B. (1985) Services Linked to Inter Modal Transportation. Paper in Regional Science. The Journal of the RSAI, 3, 253-263. 
[29] Vigarie, A. (1981) Maritime Industrial Development Areas: Structural Evolution and Implications for Regional Development. In: Hoyle, B.S. and Pinder, D.A., Eds., Cityport Industrialization and Regional Development, Belhaven Press, London, 23-37.

[30] Bi, D.D. and Fang, Y.P. (2009) Development Experience and Inspiration of the World's Advanced Seaport City. International Economics and Trade Research, 5, 35-35.

[31] Li, H.B. and Dong, D. (2014) Research on Port City Integrated Development of Dutch Rotterdam. Chinese National Conditions and Strength, 11, 70-72.

[32] Ling, L. (2010) Optimization of Development Model Based on Port Neighboring Industrial Zone of International Comparisons. Modern Finance \& Economics, 30, 62-67.

[33] Xu, P. (2008) Research on Upgrading and Transformation of Port from the Development of Duisburg Port. China Ports, 9, 54-56.

[34] Xu, Z.B. and Zhu, Y.Z. (2004) Theoretical Analysis of the Strategy on Port-City’s Integration. Journal of Zhanjiang Ocean University, 5, 7-13.

[35] Yang, Y.Y. (2010) The Demonstration Study on the Interaction between Inland River Harhour and City. Southwest Jiaotong University, Chengdu. 